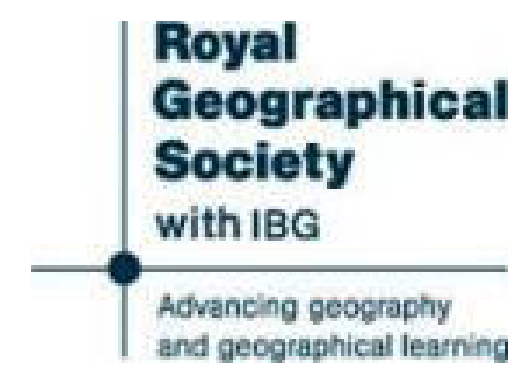

Sven Hedin and Dutreuil de Rhins in Central Asia

Through Asia by Sven Hedin; Dutreuil de Rhins, Mission Scientifique dans la Haute Asie, 189095 by Methuen

Review by: T. H. Holdich

The Geographical Journal, Vol. 13, No. 2 (Feb., 1899), pp. 159-166

Published by: The Royal Geographical Society (with the Institute of British Geographers)

Stable URL: http://www.jstor.org/stable/1774356

Accessed: 03/02/2015 01:48

Your use of the JSTOR archive indicates your acceptance of the Terms \& Conditions of Use, available at

http://www.jstor.org/page/info/about/policies/terms.jsp

JSTOR is a not-for-profit service that helps scholars, researchers, and students discover, use, and build upon a wide range of content in a trusted digital archive. We use information technology and tools to increase productivity and facilitate new forms of scholarship. For more information about JSTOR, please contact support@jstor.org. 
altitude of about 17,500 feet, far away from any lake or trace of one, and on the low hills of the left bank of the Keria river.

The topographical work was done by a sub-surveyor of the Survey of India, under my supervision.

\section{SVEN HEDIN AND DUTREUIL DE RHINS IN CENTRAL ASIA.*}

By Colonel Sir T. H. HOLDICH, K.C.I.E., C.B., R.E.

Among late works of travel, Dr. Sven Hedin's book stands pre-eminent as an exposition of scientific geography. Never was a book of this sort so welcome as at present. We have had more than enough lately of geography which is not scientific, and of popular works of travel which have added no really valuable addition to our map information; neither have they assisted to unravel any of the ethnographical riddles with which Asia and Africa abound. The unexplored spaces in High Asia are narrowing year by year, and with so much good geographical material as exists already, we want more exact information and more accurate observation to improve the old work, and fill in the new. In traversing Central Asia Sven Hedin departed from the usual Asiatic programme of exploration, and did not make Lhasa an objective. That city, which is still enveloped in a halo of most undeserved romance, has been visited often enough by Europeans to destroy the illusions which are usually draped around it, and, although there is certainly much yet to be learned about its quaint political institutions and weird customs, our knowledge can hardly ke improved by any process short of actual residence within its walls; and of this there seems little chance at present. Lhasa was visited early in the last century by Desideri, who lived in the city for thirteen years; and by Della Peuna, who was for some time there with Desideri. Then followed the Dutchman Van der Putte, who was so afraid of the reception that his Lhasa records might receive in Europe, that he destroyed them. In 1811, Mannering was sent on a political and commercial mission from India; and in 1845 the two devoted Jesuit missionaries, Huc and Gabet, were well received there. For more than fifty years no European has seen the inside of that city, although the native employés of the Indian Survey, the Pundit Nain Sing, Krishna, and the Lama Unguen (who accompanied Chandra Das) have all contributed to give us a fairly accurate account of it. Such persevering travellers as Bower, Littledale, and Bonvalot have all been refused admission, even to the neighbourhood of the sacred city; and now we have Grenard's story of De Rhins' failure. Sven Hedin wisely avoided Lhasa, and devoted his remarkable energies to investigating the phenomena which surround the natural features

* 'Through Asia,' by Sven Hedin. 2 vols. Methuen.-- Dutreuil de Rhins, Mission Scientifique dans la Haute Asie, 1890-95.' 2 vols. Paris : Leroux. 
of Central Asian geography, dividing his explorations between the elevated tableland which lies between the Kuen Luen mountains and the Himalaya, and the great central depression which forms the Tarim basin. Unlike the majority of explorers, Sven Hedin spent several years in the attentive study of the works of preceding travellers, and even took a trial trip in order to determine the best methods of proceeding. Backed by the cordial support of the King of Sweden, well supplied with funds, possessing a remarkable faculty for picking up new languages as well as for expressing himself in old ones; gifted with the eye of an artist, and the constitution of an athlete, and blessed, moreover, with that happy spirit of universal good fellowship which makes a man equally welcome in the court or the camp, it is, after all, small wonder that be succeeded in penetrating to regions untraversed before, and that he has unearthed the long-buried secrets of a forgotten phase of Asiatic civilization.

In April, 1894, Sven Hedin left the Russian outpost of Fort Pamir, on the Murghab river, and by the middle of the month found himself at the foot of the Mustagh Ata-a mountain which dominates that meridional chain which we now call the Kashgar range, running parallel to, and east of, the great Sarikol watershed which divides the drainage of the Oxus from that of the Lob Nor lake regions. There has always been a peculiar fascination about the great "Ice father," the Mustagh Ata. It claims to be the highest mountain existing north of the Himalaya; it was observed by Trotter, who accompanied the Forsyth mission to Yarkand, and its height determined from trigonometrical deductions to be 25,300 feet. Trotter named the peak Tagharma, from the plain at its foot, which is called by that name. There is, however, some doubt surrounding Trotter's determinations, from the fact that another high peak to the north of Mustagh Ata would almost certainly interfere with observations taken so far to the northeast as his base near Kashgar, and consequently it is not safe to assume that there is any peak in the range so high as 25,000 feet. At any rate, Sven Hedin's Mustagh Ata is an unmistakable feature when observed from the south-west. Its magnificent dome-shaped crest and flanking pinnacles identify it beyond possibility of error, and its position has been fixed now in direct connection with the Indian triangulation. Its height was determined by Colonel Wahab (working with the Pamir Boundary Commission) at 23,500 feet. This is, however, quite high enough. There is no really satisfactory record of any traveller ever reaching so great a height. It is not surprising that in April Sven Hedin failed in his "intention to climb to the summit of the mountain, examine its geological structure, its coat of ice mail, and the gigantic glaciers which plough their slow way down its rugged side," and that he was temporarily "compelled to return, with strength broken and eyes bandaged, to seek a warmer climate." But he returned 
to the attack in August, and during a second and third attempt he carried out at least the best part of his programme. He did not reach the summit, but he has added a store of information about the construction and movement of the Mustagh Ata glaciers which cannot fail to be of great scientific value. And we may draw attention, not only to the minute and painstaking accuracy of his observations, but to the completeness of his series of illustrations. They are clever, artistic, and admirably clear.

Then followed his adventurous journey across the desert between the Yarkand and the Khotan darya-the two great affluents of the Tarim river, which loses itself in Lob Nor ; and this part of his story contains a moral. It is a good illustration of the terrible misadventures which may befall even the most careful traveller who trusts to conjectural maps and native information. No sensational travelling tale that ever was written can exceed the absorbing interest of this narrative of a fight against the forces of nature-sand-hills and sand-storms, and the agonies of thirst. Sven Hedin lost two of his scanty following in the desert, and he would probably have lost a third, had he not been able to reach water himself, and carry a supply back in his boots for the relief of his last attendant. He lost camels and instruments, but his records were preserved by a second faithful follower, who finally struggled into safety; and there is nothing more remarkable in the book than the care with which the daily narrative of that ghastly period was sustained throughout--up to the very last day of it.

But the most interesting, as well as the most valuable, result of Sven -Hedin's explorations was the discovery of two sand-buried cities in the Takla Makan desert. The movement of the enormous sand-dunes, or sand-waves, across open desert spaces which are subject to the terrific violence of periodic wind-storms, may not inaptly be compared to that .of the sta, though the actual wave-motion is, of course, very dissimilar. Successive billows and troughs are formed, which are subject to perpetual change under the influence of wind. The gradual process of sand encroachment can be observed in the Takla Makan desert (as in the Oxus regions) by the desiccated remains of forest and vegetation in the neighbourhood of rivers. The rivers themselves are gradually being pushed eastwards, and the riverain tracts become slowly enveloped. Towns and cities which were once within reach of irrigation are lost in the sand encroachment, and as the successive waves traverse their sites they are occasionally brought to light in the troughs of the sand ocean, again to be overwhelmed by the next following wave. Sven Hedin was fortunate enough to light on two cities thus exposed to view; and nothing can be more interesting than his description of the relics which he rescued from them, which point conclusively to the existence of these cities as great Buddhist centres in ancient times. The more recent of them, which is about 120 miles north-east of Khotan, and (apparently) 
not 20 miles from the southern edge of the desert, may have existed when the Chinese pilgrims of the early centuries of our era made their religious pilgrimages through Asia. Sven Hedin thinks that Takla may be the Tu-ho-lo of the Chinese, and that the Tukhari inhabitants were a people (possibly of Tibetan origin) who migrated westward, and founded the kingdom of Tokharistan. His observations of the direction and nature of the sand encroachments that are gradually drifting to the south-west, lead him to assign a period of about two thousand years from the time of the cities' disappearance to the present limits of desert formation. The Buddhist figures and paintings which he recovered in a marvellous state of preservation, do not differ materially from those which are found in the Peshawur valley, and which belong to a period anterior to the ruthless invasions of Mahmud of Ghazni. Greek influence in design is very perceptible in all of them.

The second city, which he unearthed when following the course of the Keria river, appears to be of about the same date, though very much farther removed from the southern edge of the desert. All this part of Asia was so devastated by the Arabs in the early part of the eighth century, when the faith of Islam was forced on the population, and subsequently so cruelly given over to destruction by Chenghiz Khan in the early part of the tenth century, that it is not likely that anything in the shape of ancient building structure will ever be found to connect the modern city of Khotan with the buried city of the desert. The site of Khotan is probably as ancient as any of them, but the city itself is modern. Sven Hedin secured an interesting relic of certain ancient Christian communities at Khotan, which must have been directly connected with the Nestorian and Jacobite sects whom Marco Polo. mentions as existing at Yarkand and Kashgar. As early as the fifth and sixth centuries A.D., there were Christian bishoprics at Herat, Merve, and Samarkand, later at Yarkand, and finally in China. That at Yarkand is believed to have existed in the fourteenth century. The last Gurkhan of the Kara Kitay empire, the legendary Prester John, was a member of a Christian Kirghiz tribe called Naiman, which tribe is. well known on the Pamirs to this day. Chenghiz Khan himself, though he hunted down and destroyed Prester John, is said to have married a Christian wife. Survivals of ancient Christian ritual are still to be found amongst the Sarikolis and certain Kirghiz tribes, especially in connection with their marriage customs. *

Sven Hedin's mapping of Lob Nor, the terminal lake region of the Tarim river system, is one of the most valuable of modern additions to. the geography of Central Asia. He shows conclusively that this is a region of perpetual change, and that there have been extensive modifications of the lake outline even since the days of Prjevalsky. On the

* Vide 'Pamir Boundary Commission Report.' 
whole he finds the lake system (for there are many lakes) to be very much where Chinese geographers place it. The altitude of this central depression he marks as only 2500 feet above sea-level.

Through the waste, uninhabited regions of Northern Tibet, amongst wild yaks and "kulans" and uncouth Mongolian nomads, Sven Hedin's story takes the reader to China. From his start at Keria, south of the Takla Makan desert, past the great blue lake of Koko Nor, to his first European greeting with the young American lady doctor in Chinese dress and spectacles, who welcomed him at Tenkar, the whole story is fascinating-but we cannot follow it further. Dr. Sren Hedin sums up the extent of his travels as covering a distance rather more than from the north to the south pole. When we think of the wealth of minute. scientific observation that was acquired during that extent of travel, and note the traveller's keen interest in the ever-varying phenomena of nature, as well as in the idiosyncrasies of the uncultivated humanity that he met with on his way, we cannot feel surprised that two fairly large volumes should fail to complete his record, and that we must look for a further instalment of scientific notes to round off the full results. of his monumental expedition.

M. Dutreuil de Rhins commenced his explorations in Central Asia by adopting Khotan as a base, similarly to Sven Hedin, whom he preceded. The year 1891 was occupied in a tour to the south-east, when he visited Polour (Polu of Sven Hedin's map), and traced the course of the upper Keria, through the deep gorges which carry it from Polu to the plains. $\mathrm{He}$ visited Nia (described by Sven Hedin), and returned to winter at Khotan.

In 1892 he again traversed the road to Polu, followed up the Keria river to its source, and then struck south-west by Yeshil Kul into the lake region to the north-east of Ladak. The difficulties and hardships of travel in the mountain regions south of Polu told so severely upon his health, that it is hard to understand, from M. Grenard's description, how it was possible for him to proceed at all. Proceed he did, however, and after traversing an almost unknown region east of Ladak, he finally reached Leh, from whence he followed the Karakorum route back to Yarkand. Although he was working in regions not very remote from Indian survey, he was on comparatively new ground, and this expedition should add much to our topography of Western Tibet, although not much is perceptible in the very small-scale maps which illustrate the book.

Want of resources, combined with ill health, had so far prevented De Rhins from carrying out the full programme which he had laid down for himself at starting. But he was in no ways discouraged, and he succeeded in obtaining more substantial support for his next attempt at traversing Tibet in 1893. It is interesting to observe that about this period the author of the book encountered an old Chinese friend, 
one T'ien, at Yangi Hissar. T'ien had been decorated with the "blue button" for the success of his negotiations with "Colonel Mortimer Durand" at Gilgit, and claimed to have obtained great concessions fur China. Final arrangements for further exploration were not complete till July, at Cherchen, whence De Rhins and Grenard made their start southward for Lhasa.

From Cherchen they followed a route, which carried them to the head of the Kara Muren river, the upper branches of which are shown by their maps to be considerably south of the position assigned to them by Sven Hedin. In September they crossed the Arka Tagh by a pass about 60 miles west of Sven Hedin's, and apparently much easier. The head of the Kara Muren leads directly to it. As they had sixtyone baggage animals with them, including camels, it must be, for Tibet, a comparatively easy pass. From the Arka Tagh they travelled almost due south through an absolutely unmapped and unexplored region, until they struck Bower's route to Lhasa in about lat. $33^{\circ} \mathrm{N}$. So far they had traversed an elevated lake region with all the dreary characteristics of the uninhabited wastes of High Tibet, crossing the general strike of the plateau ranges, and discovering many small lakes, of which they counted sixteen before turning eastward. This eastward turn was taken from lake 16 (which is one of those mapped by Bower), and it carried them, during the month of November, in an east-south-east direction past four great lakes before reaching the Namtso, or Tengri Nor. Bower's route lay to the north of these lakes, touching their northern shores. De Rhins passed them on the south. From Gyaringtso to Tengri Nor they were approximately on Littledale's route, but they formed their final camp for entering into negotiations with the Lhasa authorities at the eastern end of the lake. Littledale penetrated further, and reached the watershed between the Tengri Nor and the Sangpo (the river of Lhasa) from the western side. There is, however, not much to choose between them. They were equally unsuccessful in overcoming the prejudices of the Tibetan authorities, and, although negotiations appear to have been conducted courteously and in a friendly spirit, there was finally no alternative for the French explorers but to take a northerly route again to the Chinese border, and to leave Lhasa unvisited. Half of the baggage animals had been lost in the journey to Tengri Nor, and it was necessary to refit before starting, so that it was not till January that they were again on the road. The Chinese frontier town of Sining bad now become their objective, and between it and Lhasa is a much-traversed and well-known trade route. But a route which had already been exploited by several travellers did not meet De Rhins' approval, and he decided on following the road which leads viâ Nagchu to Gye-rgoundo (Jyekundo) to Sining. Having first established connection with Bonvalot's routes at Larkang, south-east of Tengri Nor, the two 
Frenchmen quitted their camp at Zamna (? Dakmar) on January 19, for Nagchu.

From Nagchu the road to Jyekundo diverts eastwards from the regular Sining trade route, and passes through a mountainous country which encloses the headwaters and sources of the Mekong and Dichu, or Yangtse Kiang. It was not till the end of May that they reached Gye-rgoun-do (the English spelling of which is Jyekundo), and here they met with a very doubtful reception. In fact, there were unmistakab!e signs of hostility on the part of the authorities. Two marches from this place, along an unfrequented route, for which no guide was forthcoming, De Rhins met his fate. They had reached a village called Tong-bou-mdo (English spelling, Tambudia), and experienced an openly hostile reception on the part of the people. It was unfortunate that at such a juncture De Rhins should have been led into an act of retaliation for the loss of two of his baggage-ponies, which were stolen during the night. He seized the first two that came to hand, and impressed them into his service. Possibly the effects of hard work and exposure in a frame already much enfeebled by pain and sickness had told upon him, and dimmed his perceptions of the urgent necessity for that "equal mind" which Horace tells us we should be specially mindful to preserve in face of adversity; for we read previously, that at Jyekundo he had threatened to pull the ears of the chief official in the town if his wishes and demands were not complied with. Anyhow, the end soon came. The caravan was attacked, and De Rhins was mortally wounded by a Tibetan bullet before they had proceeded far from the village. There can be little doubt, from M. Grenard's account, that the attack was organized by the village authorities, and countenanced by the officials at Jyekundo. After De Rhins fell, the party was broken up and scattered, and it appears that De Rhins, alive or dead, was thrown into a. small affluent of the Dichu river. M. Grenard escaped with difficulty into Chinese territory. This happened in June, 1894, and the news reached Sven Hedin the following January. On arrival at Sining, Sven Hedin was shown, amongst other curiosities, the skull of De Rhins' murderer, but it must be extremely doubtful if the individual who fired the fatal shot was ever identified.

The most important of the geographical results of the journeys of this adventurous Frenchman is the new light thrown on the physiography of the elevated lacustrine regions of Tibet to the north-east of Ladak. We have now three routes traversing the high mountainous tableland which lies south of the central depressions of the Tarim basin, from north to south. De Rhins, Littledale, and Bonvalot have all crossed that plateau on lines which are approximately parallel; and, thanks to Sven Hedin's observations, and the care taken by M. Grenard to bring De Rhins' route to a connection with that of Bonvalot, we shall probably have a better basis for reconstructing the general map of that 
part of Tibet that we have ever yet possessed. The maps illustrative of M. Grenard's book are on far too small a scale to admit of any comparative method of testing the results of his work. It would appear, however, that the greatest difference shown in absolute position of any point, between his mapping and Sven Hedin's, is at the starting-point, Cherchen, where there is an apparent difference of some 8 or 10 miles in longitude. His position of the great chain of lakes north-west of Lhasa seems to accord fairly well with Bower's; and he has illustrated the geography of the country immediately to the north-east of Tengri Nor in a manner which no previous traveller bas attempted. The final results of his map compilation cannot fail to be very valuable. The book is written in a style which renders every page of it interesting. Too often the deadly monotony of Tibetan travel is reflected more or less in the pages of the travellers who tell the tale of it. This is not the case with M. Grenard's story; and the illustrations of the work (especially the reproduction of photographs) are as perfect as only French artists can make them.

\section{VOYAGES OF THE ZENI.*}

BY C. RAYMOND BEAZLEY, M.A.

THIs book (in writing which Mr. Lucas has enjoyed the valuable advice of Mr. C. H. Coote and Mr. Miller Christy) is unquestionably and by far the best study of the Zeno question that has yet appeared. At the same time it must not be forgotten that Dr. Gustar Storm is the Continental protagonist of the critical indictment against the Zeno stories, and that the case, which may now be considered triumphant, was first presented by that eminent Norse scholar in his 'Om Zeniernes Reiser' and 'Claudius Clavus' (1891). Admiral Zarhtmann, indeed, had, as early as 1833, subjected the Zeno narrative to a very disquieting examination in his 'Bemærkninger om de Venezianerne Zeni '; but Major in 1873 ('Voyages of the Zeni'), Desimoni in 1878 and 1885 ('Memoria interno ai viaggi dei ratelli Zeno' and 'Viaggie carta dei fratelli Zeno'), with others, made a brave attempt to rehabilitate the disputed tradition, and for some time arrested its decay. Thus John Fiske, as late as 1892, considered that Major's "heavy strokes" had so "completely demolished" Zarhtmann's objections that not enough was left to pick up ("Discovery of Ameri.a,' vol.i. p. 237). Fiske had not read Storm's already published studies, or he would not have committed himself to this unfortunate piece of rhetoric, or to the still more unlucky outburst that follows (" as

\footnotetext{
* 'The Annals of the Voyages of the brothers Nicolo and Antonio Zeno in the North Atlantic about the end of the fourteenth century, and the claim founded thereon to a Venetian discovery of America: A criticism and an indictment.' By F. W. Lucas. London: Henry Stevens, Son, \& Stiles. 1898.
} 